\title{
The present mode of teaching in the ELT classes at the Higher Secondary level in Bangladesh: Is it the practice of CLT or disguised GTM? \\ MD. Minhajul Abedin
}

\begin{abstract}
This study focuses on the current application of the Communicative Language Teaching (CLT) approach at the higher secondary level in Bangladesh. Several attempts have been taken to prove the justification of the inclusion of the CLT approach in the curriculum in our country. Though the CLT approach was not imposed suddenly on our curriculum, the implementation of CLT in the present context in Bangladesh is still questionable. In this study, concentration has been given to the disguised impact of the Grammar Translation Method (GTM) on the practice of the CLT approach in Bangladesh. It has also been an attempt to find whether we can term the current mode of CLT as modified CLT. This small scale research has been conducted at the Higher Secondary level to locate the presence of GTM in place of the CLT approach. The study has been done through questionnaire survey and interview. The result of the findings has been analyzed and some suggestions have been given on the basis of the result.
\end{abstract}

\section{Introduction}

Communicative Language Teaching (CLT) and its application in Bangladesh context are live issue in the arena of English language teaching (ELT). The teaching of English has experienced a state of turmoil in the short span of time. But we have yet not reached a point of reconciliation in the application of CLT in Bangladesh. It has been found that for some specific reasons, the application of CLT is limited to the syllabus and curriculum only (Abedin, Mojlis and Akter, 2009, p.69). In other words, Communicative Language Teaching (CLT) approach is confined to mere theory in our context and what is being implemented in the name of CLT is 
nothing but a modified version of CLT and this modification has been done in the light of Grammar Translation Method (GTM).

\section{Study Purpose}

This study aims to find out the mode of application of the CLT approach at the Higher Secondary level in Bangladesh. It is also an endeavor to explain the implementation of modified CLT in English language teaching at the Higher Secondary level in Bangladesh.

\section{Literature Review}

\subsection{GTM and CLT Approach and Their Features}

The Grammar Translation Method (GTM) has been dominating the English Language Teaching (ELT) class in Bangladesh for many years. Freeman (2000) holds the view that all the rules and features of the GTM method are very rigid and as instructors the teachers are bound to follow this method strictly and, learners are compelled to go through the passive receiving-learning process (p. 15-17). In Bangladesh also the teachers and the learners had to follow the features of the GTM as strictly as it was followed in the English language classes all over the world. Richards and Rodgers (2001) have mentioned some of the major features of the GTM as:

1. Grammar Translation is a way of studying a language that approaches the language first through detailed analysis of its grammar rules, followed by application of this knowledge to the task of translating sentences and into and out of the target language.

2. Reading and writing are the major focus; little or no systematic attention is paid to speaking or listening.

3. . . . a list of vocabulary items is presented with their translation equivalents, and translation exercise are prescribed. 
4. Much of the lesson is devoted to translating sentences into and out of the target language, and it is this focus on the sentence that is a distinctive feature of the method.

5. Accuracy is emphasized.

6. Grammar is taught deductively - that is, by presentation and study of grammar rules, which are then practiced through translation exercises.

7. The student's native language is the medium of instruction. (p. 5-6)

It is the demand of time to start an approach like CLT which will give equal importance on all the four skills of English language i.e. reading, writing, speaking and listening and bring innovation in the process of teaching and learning. In Bangladesh CLT was introduced in ELT class after 1990s (Monir, 2009, p. 7). CLT was included in the curriculum at the Higher Secondary level with a series of communicative language text books entitled English for Today (Siddique, 2004, p. 16). But ELT experts are still working on its successful implementation. For the implementation of the CLT approach in the language class, some factors are very important i.e. the number of students in the class, motivation in learning English, teachers' training, logistic support for class room activities and so on.

CLT tends to help the learners by motivating them to work with the language. In other words, it gives emphasis on the practical use of the target language (Richards and Rodgers, 2001, p. 159). In this regard, Siddique (2004) says, "the principles of CLT emphasize the issues of teaching language in a way that is systematically possible, feasible, and culturally appropriate, concurs and provides functional or genuine language" (p. 16). Harmer (2001) says:

The communicative approach-or CLT is the name which was given to a set of beliefs which included not only a re-examination of what aspects of language to teach, but also a shift in emphasis is how to teach. The 'what to teach' aspect of the communicative approach 
stressed the significance of language functions rather than focusing solely on grammar and vocabulary. (p. 84)

Piepho (1981) mentions some levels of objectives in the CLT approach as:

1. an integrative and content level( language as a means of expression).

2. a linguistic and instrumental level (language as a semiotic system and an object of learning).

3. an effective level of interpersonal relationships and conduct (language as a means of expressing values and judgments about oneself and others).

4. a level of individual learning needs (remedial learning based on error analysis)

5. a general educational level of extra-linguistic goals. (p. 8)

\subsection{Teacher's Role and Learner's Role in Learner-Centered Classroom}

For effective implementation of the CLT approach, the teachers should have proper knowledge regarding their (teachers') roles and learners' roles in the class. Learner-centered classroom is one of the core features of the CLT approach (Harmer, 2001, p. 84-85). In a 'learner-centered' class, says Harmer (2001), the teachers play different roles, i.e. the role of a facilitator, a controller, an organizer, an assessor, a promoter, a participant, a resource, a tutor and an observer. On the other hand, according to Breen and Candlin (1980) in a learner-centered ELT class, the teachers are to play the role of facilitator, participant and researcher-learner (p.99). Breen and Candlin, (1980) describe learners' roles within CLT in the following terms:

The role of the learner as negotiator- between the self, the learning process, and the object of learning-emerges from and interacts with the role of joint negotiator within the group and within the classroom procedures and activities which the group undertakes. The implication for the learner is that he should contribute as much as he gains, and thereby learn in an interdependent way. (p. 110) 


\subsection{Product and Process Oriented Syllabus}

According to Widdowson (1987), syllabus is the specification of a teaching program that describes a particular subject for a particular group of learners (p. 65). Nunan (1988) has defined two types of syllabus i.e. Product oriented syllabus and Process oriented syllabus (p. 27-40). In a product oriented syllabus the major focus is given on the learning outcome whereas in a process oriented syllabus the emphasis is rather on the learning process and on the learners (Nunan, 1988, p. 27-40). So, it may be said that product oriented syllabus is meant for a teacher-centered classroom and process oriented syllabus is for the learner-centered classroom.

\subsection{Teachers' Selection of Appropriate Task}

Ellis (1985) opines that it is very important to create communicative situation in the classroom and in this regard, the spontaneous participation of the second language learner can play an important role (p.182). Selection of the exact learning activities for the students is very important. Teachers are to choose appropriate tasks for the learners to practice in the classroom so that the learners may not feel extra pressure; rather they (learners) can involve themselves in the learning process using their creativity and analytical ability. While selecting any effective task for the learners, the teachers should think about the social surrounding, the culture and, the ability and aptitude of the learners. In this regard Ur (1996) says:

The success of group work depends to some extent on the surrounding social climate, and on how habituated the class is to using it; and also . . . on the selection of an interesting and stimulating task whose performance is well within the ability of the group. (p. 232-3)

\section{Method}

According to Farhana (2010), quantitative research refers to counting and measuring of numerical data analysis (p. 37). This study is quantitative in 
nature in the sense that counting and measuring of numerical data is done in this study. The main source of data was questionnaire survey. A short interview session was also arranged where one fixed open-ended question was asked to the teachers. After analyzing the findings gathered from the questionnaire survey the results were analyzed and tabulated to show consequence and then the result were converted into percentage.

\subsection{Participants}

Through questionnaire survey and interview, the data was collected from ten (10) colleges of Dhaka city which follow the national curriculum. Three English language teachers and ten students from each college were selected on random basis for questionnaire survey and the total number of surveyed students was 100, whereas the number of teachers was 30. For interview, one English language teacher from each college was selected. Data was collected from Dhaka City College, Viqarunnisa Noon College, Dhaka Commerce College, Siddheswari Girls' College, Dhaka Residential Model College, Cambrian College, Ideal College, College of Development Alternative (CODA), Stamford College and Trust College.

\subsection{Survey instrument}

On the basis of the features of the CLT approach and the GTM, two questionnaires were prepared- one for the teachers and the other for the students. Questionnaire for the teachers consisted of five multiple choice questions whereas the students' questionnaire consisted of nine multiple choice questions. For short interview mp3 recorders were used.

\section{Data analysis}

\subsection{Analysis of Students' Responses}

First question was set to know whether the teachers delivered their lectures in English, and it was found that 27\% teachers delivered lectures in English, whereas $73 \%$ teachers sometimes did it. Through the second question the students were asked whether their English language teachers 
gave emphasis on translation of their text, and surprisingly it was found that $100 \%$ teachers gave emphasis on translation. The next question was regarding the scope of the students' interaction in English in the classroom situation. Here, $15 \%$ students confirmed that they got chance of interaction in English whereas 57\% students did not and 28\% students sometimes got it. Then the students were asked a question regarding their preferred types of comprehension and $82 \%$ students gave their answer in favor of 'seen comprehension' whereas 18\% students gave answer in favor of 'unseen' comprehension. In the fifth question students were asked about their preferred way of learning English. From the students' reply, it was found that $42 \%$ students preferred learning English through grammar whereas $58 \%$ students preferred communication as a medium for learning English language. The next question was set to know whether memorization was an important part in their English language class, and here $90 \%$ students confirmed that memorization was an important part in their learning process. Through the question no.7 students were asked that on which skills their teachers gave emphasis in their English class. From the responses to this question, it was found that $23 \%$ students confirmed their teachers' emphasis on all the four skills of English language in their language class whereas $77 \%$ students admitted that the emphasis was given only on reading and writing skills. In the next question, the students were asked about their way of building up vocabulary, and it was found that $72 \%$ students took the help of memorization whereas $28 \%$ students tried to increase vocabulary by using new words while speaking and writing. Through the last question, it was inquired whether the teachers were too much rigid to the mistakes of the students, and here surprisingly $78 \%$ students confirmed their teachers' rigidity regarding the matter. 


\section{Table 1}

\begin{tabular}{|l|l|l|l|}
\hline Question topic & \multicolumn{3}{|c|}{ Responses } \\
\hline $\begin{array}{l}\text { 1. Lecture is given in } \\
\text { English or not }\end{array}$ & $\begin{array}{l}\text { Yes-27\% } \\
(27 \text { students) }\end{array}$ & $\begin{array}{l}\text { No } \\
\text { (no } \\
\text { students) }\end{array}$ & $\begin{array}{l}\text { Sometimes-73\% } \\
\text { (73 students) }\end{array}$ \\
\hline $\begin{array}{l}\text { 2. Emphasis on the } \\
\text { translation of text }\end{array}$ & $\begin{array}{l}\text { Yes-100\% } \\
(100 \\
\text { students) }\end{array}$ & No-0\% & Sometimes -0\% \\
\hline $\begin{array}{l}\text { 3. Scope of interaction in } \\
\text { English }\end{array}$ & $\begin{array}{l}\text { Yes-15\% } \\
(15 \text { students) }\end{array}$ & $\begin{array}{l}\text { No-57\% } \\
\text { (57 } \\
\text { students) }\end{array}$ & $\begin{array}{l}\text { Sometimes-28\% } \\
\text { (28 students) }\end{array}$ \\
\hline $\begin{array}{l}\text { 4. Preferred comprehension } \\
\text { type }\end{array}$ & $\begin{array}{l}\text { Seen-82\% } \\
\text { (82 students) }\end{array}$ & $\begin{array}{l}\text { Unseen-18\% } \\
\text { (18 students) }\end{array}$ \\
\hline $\begin{array}{l}\text { 5. Preferred way of } \\
\text { learning English }\end{array}$ & $\begin{array}{l}\text { Through grammar-42\% } \\
(42 \text { students) }\end{array}$ & $\begin{array}{l}\text { Through } \\
\text { communication-58\% } \\
\text { (58 students) }\end{array}$ \\
\hline $\begin{array}{l}\text { 6. Room of memorization } \\
\text { in English class }\end{array}$ & $\begin{array}{l}\text { Yes-90\% } \\
\text { (90 students) }\end{array}$ & $\begin{array}{l}\text { No-10\% } \\
\text { (10 students) }\end{array}$ \\
\hline $\begin{array}{l}\text { 7. Emphasized skill } \\
\text { All four } \\
\text { skills-23\% } \\
(23 \text { students) }\end{array}$ & $\begin{array}{l}\text { Reading \& } \\
\text { writing } \\
\text { only-77\% } \\
\text { (77students) }\end{array}$ & $\begin{array}{l}\text { Speaking \& } \\
\text { listening } \\
\text { skill- 0\% }\end{array}$ & $\begin{array}{l}\text { Others- } \\
0 \%\end{array}$ \\
\hline $\begin{array}{l}\text { 8. Way of increasing } \\
\text { vocabulary }\end{array}$ & $\begin{array}{l}\text { Through } \\
72 \% \\
\text { memorization- }\end{array}$ & $\begin{array}{l}\text { Through practice-28\% } \\
\text { (28 students) }\end{array}$ \\
\hline $\begin{array}{l}\text { 9. Rigidity of teacher about } \\
\text { mistakes }\end{array}$ & $\begin{array}{l}\text { Yes-78\% } \\
\text { (78 students) }\end{array}$ \\
\hline
\end{tabular}

\subsection{Analysis of Teachers' Responses}

The first question for the teacher was set to know the teachers' preferred method of teaching English, and here it was found that $60 \%$ teachers preferred CLT; $6.67 \%$ GTM and $33.33 \%$ preferred the combination of CLT and the GTM. In the next question, the teachers were asked whether they adopt translation as a mode of teaching. It was observed that $26.67 \%$ teachers adopted translation technique whereas $73.33 \%$ did not. In the third question, the teachers were asked to which factor they (teachers) should 
give more importance- students' ability of communication in English or students' tendency of getting good grade. From the reply to the third question, it was found that only $20 \%$ teachers gave importance to students' communicative ability whereas $80 \%$ teachers gave importance to students' getting good grades. In the next question the teachers were asked whether the class size acts as a bar in the way of applying the CLT approach in the class. Here $93.33 \%$ teachers confirmed the fact that the class size acted as a bar to their way of teaching whereas $16.67 \%$ thought that class size was not a problem for them in English language teaching. The last question was set to know whether the teachers enjoy enough privilege to implement the CLT approach in the class, and it was found that $56.67 \%$ teachers admitted that they felt different kinds of difficulties in implementing the CLT approach in the class whereas $43.33 \%$ teachers came up with the idea that they enjoyed enough privilege to implement the CLT approach in the class.

\section{Table 2}

\begin{tabular}{|l|l|l|l|}
\hline Question topic & \multicolumn{3}{|c|}{ Responses } \\
\hline $\begin{array}{l}\text { 1. Preferred method of } \\
\text { English teaching }\end{array}$ & $\begin{array}{l}\text { CLT-60\% } \\
\text { (18 teachers) }\end{array}$ & $\begin{array}{l}\text { GTM- 6.67\% } \\
\text { (2 teachers) }\end{array}$ & $\begin{array}{l}\text { Combination- } \\
33.33 \% \\
(10 \text { teachers) }\end{array}$ \\
\hline $\begin{array}{l}\text { 2. Translation } \\
\text { technique as a mode of } \\
\text { teaching }\end{array}$ & $\begin{array}{l}\text { Yes-26.67\% } \\
\text { (8 teachers) }\end{array}$ & $\begin{array}{l}\text { No -73.33\% } \\
\text { (22 teachers) }\end{array}$ \\
\hline $\begin{array}{l}\text { 3. Which one should } \\
\text { be given more } \\
\text { importance }\end{array}$ & $\begin{array}{l}\text { On communicative } \\
\text { ability-20\% } \\
\text { (6 teachers) }\end{array}$ & $\begin{array}{l}\text { On students' getting good } \\
\text { grade- 80\% } \\
\text { (24 teachers) }\end{array}$ \\
\hline $\begin{array}{l}\text { 4. Class size as an } \\
\text { obstacle }\end{array}$ & $\begin{array}{l}\text { Yes-93.33\% } \\
\text { (28 teachers) }\end{array}$ & $\begin{array}{l}\text { No-6.67\% } \\
\text { (2 teachers) }\end{array}$ \\
\hline $\begin{array}{l}\text { 5. Teacher's privilege } \\
\text { to implement CLT }\end{array}$ & $\begin{array}{l}\text { Yes-43.33\% } \\
(13 \text { teachers) }\end{array}$ & $\begin{array}{l}\text { No-56.67\% } \\
\text { (17 teachers) }\end{array}$ \\
\hline
\end{tabular}




\subsection{Discussion of the Findings}

From the responses of the students and the teachers, some different but interesting data were found. Some of the information gathered from questionnaire survey and interview of the teachers contradicted each other. Most of the teachers claimed that they followed the CLT approach mentioned in the curriculum. From the interview session, it became clear that some teachers did not have enough idea regarding the approach. On the other hand, some teachers claimed that the CLT approach required certain supports like, logistic support, appropriate class size, enough time to complete syllabus etc which they did not get. The teachers, who followed the mixture of CLT and the GTM, said from their experience that in the Bangladeshi context both the classroom and the learners were not yet prepared for the application and adoption of the CLT approach. They further opined that since the students required the use of Bengali in the classroom, mixture of the (CLT and the GTM) two will be more effective here. So, here some of the teachers still preferred translation as a mode of teaching English. Some teachers gave emphasis on the communication ability of the students, whereas most of the teachers gave emphasis on students' getting good grades. But, as the followers of the CLT approach, the maximum number of teachers should have preferred communication ability of the students. From students' responses, it came to light that the teachers still used Bangla as the medium of teaching English and at the same time they gave emphasis on translation of texts. The learners here hardly found any scope of interaction in English with the teachers and the class-mates. Students' preference for 'seen comprehension', way of learning vocabulary, memorizing tendency and the teachers' emphasis on the accuracy of the students, no doubt, conformed to the features of the GTM method. It is very interesting that still a huge number of students wanted to learn English language through grammar.

From the interview session it also came to light that the teachers remained always under pressure to complete syllabus within time fixed by the authority. Another important information was that the teachers 
remained under pressure for another reason and that is for students' getting good grade. So, it can be said that it is the system which has compelled the teachers to turn the process oriented syllabus into product oriented syllabus. Here the ultimate goal of teaching is fixed by the college authority and goal which is given emphasis in the curriculum is not taken into account seriously.

\section{Recommendations}

1. Students' active involvement in the classroom should be encouraged. Attention should be given on active class participation of the students rather than on memorization. Memorization is totally opposite to the principle of the CLT approach.

2. There should be a change in the assessment procedure because frequent exams enhance feeling of anxiety in the mind of the students. Assessment can be done through class participation.

3. Students' apprehension of English as a foreign language should be removed by motivation and making the learners involved in the practical use of the language.

4. Teachers should not adhere to their old belief based on their own learning and teaching experience because sometimes too much rigidity obstructs the teachers to be innovative in the classroom.

5. Teachers should be equipped with the logistic supports so that they can adapt new circumstances.

6. Time span for the English language class should be increased because pressure from the authority for the completion of syllabus within the limited time sometimes acts as a barrier to the class.

7. Teachers should give more importance on the learning process than learning outcome. 
8. The number of students should be minimized for the sake of better learning.

9. Teaching strategies should be changed according to learners' need. So, to consider some factors like, students' belief and expectation about learning and teaching, and needs analysis are very important.

10. Criticism should be constructive rather than unhelpful. Otherwise, it will hamper the learning process of the students. Teachers should not be too much rigid to the accuracy of the students.

11. All the four skills should be given equal importance in the assessment procedure and students should be given the opportunity to develop these four skills as inseparable part of their learning process. 


\section{References}

Abedin, M., Mojlis, K., Akter, S. (2009). Listening skill at tertiary level: a reflection. The Dhaka University Journal of Linguistics, 2(3), 69-90.

Breen, M., \& Candlin, C.N. (1980). The essentials of a communicative curriculum in language teaching. Applied Linguistics, 1(2), 89-112.

Ellis, R. (1985). Understanding second language acquisition. Oxford: Oxford University Press.

Farhana, B. (2010). Bangladeshi Tertiary Level Students' Common Error in Academic Writing. Diss. BRAC University.

Freeman, L.D. (2000). Techniques and Principles in Language Teaching. Oxford: Oxford University Press.

Harmer, J. (2001). The practice of English language teaching. Edinburgh: Person Education.

Monir, M. (2009). English language teaching in the rural context: secondary level. Unpublished master's thesis, East West University, Mohakhali, Dhaka.

Nunan, D. (1988). Syllabus design. Oxford: Oxford University Press.

Piepho, H.E. (1981). Establishing English in the teaching of English. Richards, J.C., \& Rodgers, T.S. (2001). Approaches and methods in language teaching. Cambridge: Cambridge University Press.

Richards, J.C., \& Rodgers, T.S. (2001). Approaches and methods in language teaching. Cambridge: Cambridge University Press.

Siddique, R. (2004). CLT: Another Assumed Ideal from the West? The Dhaka University Studies, 61(1), 15-26.

Ur, P. (1996). A course in English language teaching. Cambridge: Cambridge University Press.

Widdowson, H.G. (1987). Aspects of syllabus design in M. Tickoo (ed.): Syllabus Design: The state of the art. Singapore: Regional English Language Centre. 


\section{Appendix}

\section{Questionnaire for the teachers}

1. Do you have preference for any one of the following?
a. CLT
b. GTM
c. Combination of $\mathrm{a}$ and $\mathrm{b}$

2. Do you apply translation technique as a mode of teaching?
a. Yes
b. No

3. Which one do you think should be given more importance?
a. On communication ability
b. On students' good grade

4. Does the class size act as an inhibition in applying the CLT approach?
a. Yes
b. No

5. Do you think you enjoy enough privilege to implement the CLT approach in the class room?
a. Yes
b. No

\section{Questionnaire for the students}

1. Does your teacher use English language when he/she delivers his/her lecture in the English class?
a. Yes
b. No
c. Sometimes

2. Does your teacher give emphasis on translation of texts?
a. Yes
b. No
c. Sometimes

3. Do you get chance to interact in English with your teacher and other students in the class?
a. Yes
b. No
c. Sometimes 
4. Which type of reading comprehension do you prefer?
a. Seen
b. Unseen

5. Which one do you prefer?

a. To learn English language through grammar

b. To learn English language through communication

6. Does memorization take place in your English language class?
a. Yes
b. No

7. Which skills are given priority in your English language class?
a. All four skills
b. Reading \& Writing only c. Speaking \& Listening d. Others

8. How do you increase your vocabulary?

a. Through memorization b. Practicing new words in speaking/writing

9. Do you feel your English language teacher is too much rigid about your mistakes?
a. Yes
b. No

Question for the interview session with the teachers:

What is your idea about the present mode of application of the CLT approaches in the ELT classes at the Higher Secondary level in Bangladesh? 